\title{
ARTIKELEN
}

\section{Wie stuurt de veiligheidsregulering van de (deels) zelfrijdende auto?}

\author{
K.A.P.C. van Wees
}

\section{Inleiding}

De ontwikkeling en toepassing van rijtaakautomatiserende systemen zijn de afgelopen jaren in een stroomversnelling geraakt. Steeds geavanceerdere systemen, veelal aangeduid als Advanced Driver Assistance Systems (ADAS), vinden hun weg naar de markt. Zo hebben verschillende autofabrikanten modellen geïntroduceerd die onder bepaalde (beperkte) condities automatisch kunnen rijden, zij het dat de bestuurder nog wel continu moet blijven opletten of alles goed gaat. Autofabrikanten en techbedrijven zoals Waymo en Uber zetten grootschalig in op de ontwikkeling van volledig autonome voertuigen. Van automatisering van de rijtaak wordt veel verwacht, niet alleen in termen van verhoging van het rijcomfort, besparing op chauffeurskosten, verbetering van de doorstroming op de weg en vermindering van de milieubelasting, maar vooral ook op het vlak van de verkeersveiligheid.

Er bestaan hooggespannen verwachtingen over de gunstige effecten van voertuigautomatisering op de verkeersveiligheid. Deze verwachtingen worden vooral gevoed door het feit dat meer dan $94 \%$ van de ongevallen wordt toegeschreven aan menselijke fouten. ${ }^{1}$ Door betere waarnemingscapaciteiten en grotere handelingssnelheid kan de techniek veel ongelukken, en daarmee gepaard gaand menselijk leed, helpen voorkomen, zo is de veronderstelling. ${ }^{2}$ Anderzijds zal de technologie ook haar eigen kwetsbaarheden kennen. Daarbij valt te denken aan mogelijk

1 S. Singh, Critical Reasons for Crashes Investigated in the National Motor Vehicle Crash Causation Survey, NHTSA, DOT HS 812 115, februari 2015; zie www-nrd.nhtsa.dot.gov/pubs/812115.pdf.

2 AAA Foundation for Traffic Safety, Potential Reductions in Crashes, Injuries, and Deaths from LargeScale Deployment of Advanced Driver Assistance Systems, 2018. Daarbij dient wel te worden bedacht dat deze voorspellingen veelal gebaseerd zijn op schattingen op basis van statistieken over ongevallen. Er wordt dan op basis van frequenties van bepaalde typen ongevallen (bijv. kopstaartbotsingen) een schatting gemaakt van het potentiële effect van diverse vormen van ADAS/ geautomatiseerde voertuigen. Bij deze schattingen worden de mogelijke effecten van een gebrekkige sensitiviteit en specificiteit en een eventuele gedragsadaptatie doorgaans niet meegenomen. 
falende hardware, softwarebugs, gebrekkige interactie tussen mens en machine, ${ }^{3}$ en de mogelijkheid dat voertuigsystemen gehackt kunnen worden. Hoewel over frequentie en ernst van de daadwerkelijke problemen in de toekomst weinig te zeggen valt, maakt een aantal ongevallen met semiautonome voertuigen in binnen- en buitenland in ieder geval duidelijk dat de techniek nog verre van perfect is. ${ }^{4}$

Vanuit maatschappelijk oogpunt is het zaak dat enerzijds de voordelen van deze technologie zo veel mogelijk worden benut, terwijl anderzijds de risico's worden geminimaliseerd. Hier ligt vanzelfsprekend een belangrijke taak voor de overheid, die immers dient te waken over de veiligheid van haar burgers. Het is onbetwist dat het niet louter aan de krachten van de markt kan worden overgelaten om het veiligheidsniveau van motorrijtuigen te bepalen. Hoewel het marktmechanisme zonder twijfel een belangrijke drijfveer vormt achter de verbetering van de voertuigveiligheid - de introductie, en het toenemend gebruik, van bijvoorbeeld airbags en elektronische stabiliteitscontrole (ESP) is geenszins het gevolg geweest van enig wetgevend optreden door de overheid -, betekent dit niet dat de economische beginselen van vraag en aanbod steeds tot een maatschappelijk wenselijk niveau van veiligheid leiden. Het marktmechanisme kent namelijk belangrijke tekortkomingen. ${ }^{5} \mathrm{Zo}$ is de doorsneeconsument niet deskundig genoeg om technisch complexe producten zoals motorrijtuigen te beoordelen op hun veiligheidsmerites, mede in vergelijking tot soortgelijke modellen. ${ }^{6}$ Voorts is het een bekend gegeven dat risico's door consumenten vaak onjuist worden ingeschat. Daarbij speelt met name de geringe kans om daadwerkelijk betrokken te raken bij een (ernstig) verkeersongeval een rol. Door deze toevalsfactor zijn consumenten geneigd het risico op een ongeval te onderschatten of op de koop toe te nemen. ${ }^{7}$ Een derde belangrijke tekortkoming van het marktmechanisme houdt verband

3 Daarbij valt te denken aan: een afname van situatiebewustzijn (doordat je minder op het verkeer gaat letten, weet je niet wat er om je heen gebeurt en waar dat in de volgende seconden toe kan leiden); een te lage taakbelasting, waardoor je andere dingen gaat doen of je minder concentreert op de rijtaak; een teveel aan vertrouwen in ADAS, waardoor je niet meer controleert of het systeem goed functioneert; en 'mode confusion': doordat je je vergist in de stand waarin het systeem staat (bijv. 'uit' in plaats van 'aan'), houd je er op een onjuiste manier rekening mee. Zie W.P. Vlakveld, Veiligheidseffecten van rijtaakondersteunende systemen, Den Haag: SWOV 2019, p. 11.

4 Zie o.a. Onderzoeksraad voor Veiligheid, Wie stuurt? Verkeersveiligheid en automatisering in het wegverkeer, Den Haag, november 2019, p. 30 e.v.

5 L.T. Visscher, M. Faure \& F. Weber, 'Geoorloofde maar gezondheidsbedreigende producten en diensten: een rechtseconomische visie op regulering en aansprakelijkheid', AV\&S 2018, afl. 4, p. 86-87; M. van Dam, Verkeersongevallen. Een rechtseconomisch, empirisch en positiefrechtelijk onderzoek naar de werking van aansprakelijkheid, verzekering en veiligheidsregulering in het verkeer (diss. Maastricht), Den Haag: Boom Juridische uitgevers 2001, p. 294 e.v.

6 De overheid kan consumenten van de nodige informatie voorzien, opdat zij beter in staat zijn een weloverwogen aankoopbeslissing te nemen. Een goed voorbeeld vormt het Euro New Car Assessment Programm (Euro NCAP), dat o.a. door de Nederlandse overheid en de Europese Commissie wordt ondersteund. Euro NCAP is ook begonnen om rijtaakautomatiserende systemen in zijn beoordeling te betrekken. Zie R. Schram e.a., Euro NCAP's First Step to Assess Automated Driving Systems (zie https://cdn.euroncap.com/media/17731/24esv-000277.pdf).

$7 \quad$ M. van Dam 2001, p. 299. 
met externe veiligheidseffecten. Motorrijtuigen leveren niet alleen gevaar op voor de gebruikers van dat voertuig (die veelal ook degenen zijn die het voertuig aanschaffen), maar ook voor andere (al dan niet gemotoriseerde) verkeersdeelnemers ('innocent bystanders'). ${ }^{8}$

Het is dan ook niet verrassend dat het traditionele voertuigveiligheidsbeleid in belangrijke mate berust op door de overheid dwingend voorgeschreven voertuigeisen gekoppeld aan een voorafgaand aan marktintroductie uit te voeren toetsing of aan deze eisen is voldaan. Vastgesteld kan echter worden dat de huidige technologische ontwikkelingen op het terrein van de voertuigautomatisering het bestaande publiekrechtelijk reguleringsinstrumentarium op de proef stellen. Daarbij spelen met name de snelheid van de ontwikkelingen, de onzekerheid over de veiligheidseffecten en de nieuwsoortige aard van de technologie en de daaraan verbonden risico's een rol. Een van de vragen die daarbij rijst, is die naar het potentieel van het privaatrecht om als aanvullend of substituut-reguleringsinstrument te fungeren. Op deze vraag zal in paragraaf 4 nader worden ingegaan. Alvorens daaraan toe te komen, zal in paragraaf 2 eerst kort worden ingegaan op de verschillende niveaus van automatisering en autonomie in relatie tot rijtaakautomatiserende technologie, om vervolgens aandacht te besteden aan het publiekrechtelijk kader en de knelpunten die de ontwikkeling van de (deels) zelfrijdende auto op dit terrein met zich brengt (par. 3).

\section{Niveaus van automatisering en autonomie}

Als het gaat over automatisering van de rijtaak worden vaak begrippen als 'zelfrijdend' en 'autonoom' gebruikt. Deze begrippen suggereren dat we te maken hebben met een voertuig dat in staat is geheel zelfstandig, dus zonder enige bemoeienis of supervisie van een bestuurder van vlees en bloed, door het verkeer te bewegen. Van een dergelijke mate van autonomie is in werkelijkheid nog geen sprake en de volledig zelfrijdende auto zal ook nog enige tijd op zich laten wachten. We bevinden ons nu en in de komende jaren in een situatie waarin de techniek weliswaar de controle over het voertuig deels of geheel kan overnemen, maar waarbij ter waarborging van de veiligheid een bepaalde mate van toezicht door de bestuurder onmisbaar blijft. Voor een goed begrip is het nuttig om diverse niveaus van automatisering te onderscheiden. Een veel gehanteerde indeling is die van de SAE International. ${ }^{9}$ Daarin worden de volgende vijf niveaus van automatisering onderscheiden:

1 driver assistance;

2 partial automation;

3 conditional automation;

4 high automation;

8 M. van Dam 2001, p. 295.

9 SAE International, 'Taxonomy and Definitions for Terms Related to Driving Automation Systems for On-Road Motor Vehicles', versie 30 september 2016 (zie sae.org/standards/content/ j3016_201609). 


\section{5 full automation.}

Een belangrijk onderscheid is dat tussen niveau 2 ('partial automation') en hogere niveaus van automatisering. Bij niveau 2 kan het voertuig zowel automatisch de snelheid en volgafstand regelen (remmen en gas geven) als automatisch sturen, waardoor het voertuig onder bepaalde condities automatisch kan rijden. Van de bestuurder wordt echter nog steeds verlangd dat hij blijft opletten en in staat is om zo nodig direct in te grijpen (hands-off-feet-off, maar eyes-on-brain-on). De meest geavanceerde systemen die nu op de markt zijn, zoals de Auto-pilot van Tesla, de Volvo Pilot Assist en de Drive Pilot van Mercedes Benz, bevinden zich feitelijk op niveau 2. Deze systemen zijn in staat onder bepaalde omstandigheden, zoals tamelijk rechte en goed belijnde wegen, automatisch te rijden, maar het zijn slechts systemen die beogen de bestuurder te ondersteunen en de bestuurder niet ontslaan van de taak continu het verkeer en het functioneren van het systeem in de gaten te houden. ${ }^{10}$ We zouden in dit verband van semizelfrijdende auto's kunnen spreken. Problematisch bij een dergelijke continue supervisieplicht van de bestuurder is dat we iets van de bestuurder verlangen waarvan de wetenschap heeft aangetoond dat we er slecht in zijn: gefocust blijven, terwijl onze taak grotendeels uit handen is genomen (een probleem van onderbelasting in plaats van overbelasting). Illustratief in dit verband is onderzoek waaruit bleek dat bestuurders in hooggeautomatiseerde auto's er moeite mee hebben om voortdurend te blijven opletten, en dat ze geneigd zijn andere dingen te gaan doen onder het rijden, ook wanneer hun verteld is dat de ADAS in hun auto niet $100 \%$ betrouwbaar is. ${ }^{11}$

Bij niveau-3-systemen en hoger ligt de rolverdeling tussen bestuurder en voertuig wezenlijk anders. Bij niveau 3 ('conditional automation') wordt niet langer van de bestuurder $^{12}$ verlangd dat hij continu zijn aandacht blijft richten op het verkeer en het goed functioneren van het systeem. De gedachte is dat de bestuurder tijdens de fase waarin de auto op de automatische piloot rijdt, zich met andere

10 Zo valt op de website van Tesla te lezen: 'De huidige functies vereisen actief toezicht van de bestuurder en maken de auto niet zelfrijdend.' Zie www.tesla.com/nl_NL/autopilot (geraadpleegd op 4 mei 2020).

11 In dit Zweedse onderzoek bleek dat na een halfuur rijden in een hooggeautomatiseerde auto $28 \%$ van de deelnemers tegen een geparkeerde opblaasauto botste, hoewel ze de handen aan het stuur hielden en ze gewaarschuwd werden wanneer ze van de weg af keken (T.W. Victor e.a., 'Automation Expectation Mismatch: Incorrect Prediction Despite Eyes on Threat and Hands on Wheel', Human Factors (60) 2018, afl. 8, p. 1095-1116).

12 In deze bijdrage wordt het begrip bestuurder in een bredere betekenis gebruikt dan daaraan in de zin van de Wegenverkeerswet kan worden toegekend. Immers, gesteld kan worden dat een bestuurder die de rijtaak uit handen heeft gegeven aan een technologisch systeem en van wie niet langer verlangd wordt dat hij zijn aandacht bij het verkeer houdt, niet langer als bestuurder in de zin van art. 1 lid 1 onder $\mathrm{n}$ beschouwd kan worden (zie nader N.E Vellinga, W.H. Vellinga \& K.A.P.C. van Wees, 'Testen van autonome of zelfrijdende auto's op de openbare weg', VR 2016, p. 219-227, hier p. 223-224). Men zou voor die situaties in die zin dan ook beter van toezichthouder of gebruiker kunnen spreken. Voor de leesbaarheid is er evenwel voor gekozen ook in die situaties van bestuurder te spreken ter aanduiding van de persoon die op de bestuurdersstoel zit en die gepland of ongepland de rijtaak weer zelf ter hand moet kunnen nemen. 
zaken kan bezighouden, zoals het lezen van e-mails of het kijken van een film. ${ }^{13}$ Hij hoeft in beginsel slechts beschikbaar te zijn om het stuur over te nemen als het systeem aangeeft dat zijn ingrijpen nodig is. ${ }^{14} \mathrm{We}$ zouden dit niveau ook parttime zelfrijdend kunnen noemen (hands-off-feet-off, eyes-off-brain-on). Wat in dit verband voldoende reactietijd is en hoe een dergelijke rolverdeling tussen voertuigautomatisering en bestuurder qua systeemontwerp verantwoord gestalte gegeven kan worden, is nog een cruciale onderzoeksvraag. ${ }^{15}$ In dit verband is van betekenis dat onderzoek, onder andere naar het gebruik van automatisering in de luchtvaart, uitwijst dat mensen relatief veel reactietijd nodig hebben om de controle weer over te nemen als er een beroep op hen wordt gedaan om in te grijpen. ${ }^{16}$

Niveau 4 ('high automation') verschilt van niveau 3 in die zin dat het voertuig in staat is automatisch het voertuig in een minimaal gevaarzettende situatie (zogenaamde minimal risk condition) te brengen als de bestuurder niet reageert op een oproep tot overnemen van de besturing. Daarbij kan worden gedacht aan het op de vluchtstrook met de alarmlichten aan tot stilstand brengen van het voertuig. Het verschil met niveau 3 is dus dat de bestuurder niet langer nodig is om evident gevaarlijke situaties te vermijden als het systeem op zijn operationele grenzen stuit. Anderzijds blijft een bestuurder/operator vereist, omdat het voertuig niet in staat is onder alle omstandigheden autonoom te rijden (het operationeel bereik kan bijvoorbeeld beperkt zijn tot een bepaald type wegen of bepaalde weerscondities). Dit is het verschil met automatiseringsniveau 5 ('full automation'). Op dat hoogste automatiseringsniveau is het voertuig in staat onder alle condities waarin het terecht kan komen autonoom te rijden zonder op enig moment voor het (veilig) functioneren afhankelijk te zijn van bemoeienis of supervisie van een menselijke bestuurder of operator.

\section{Publiekrechtelijk toelatingskader}

Op het terrein van de voertuigveiligheid spelen dwingende overheidsvoorschriften ten aanzien van de constructie en werking van motorvoertuigen, onderdelen

13 De mate waarin de bestuurder dat in verkeersrechtelijke zin onbestraft kan doen, is overigens afhankelijk van nationale wetgeving. Hoewel we in de Nederlandse verkeerswetgeving geen specifieke bepaling kennen dat je je handen aan het stuur moet houden - rijden met losse handen en andere gevaarlijke gedragingen kunnen mogelijk wel worden aangepakt door toepassing van art. 5 WVW, het algemeen verbod op het veroorzaken van gevaar of hinder op de weg -, is het bijv. wel expliciet verboden om tijdens het rijden een mobiele telefoon vast te houden (zie art. $61 \mathrm{a}$ RVV).

14 Tevens dient hij, aldus de SAE-omschrijving, te reageren op evidente problemen bij het functioneren van andere onderdelen van het voertuig dan het betreffende rijtaakautomatiserende systeem ('as to DDT performance relevant system failures in other vehicle systems').

15 J.M. Anderson e.a., Autonomous Vehicle Technology. A Guide for Policymakers, Santa Monica, CA: RAND 2016, p. 68; A.P. van den Beukel, Driving Automation Interface Design: Supporting Drivers' Changing Role (diss. Enschede), 2016, doi: 10.3990/1.9789036542395.

16 Automated Vehicles. A Joint Preliminary Consultation Paper (Law Com CP 240, Scot Law Com DP 166), Londen/Edinburgh: Law Commission \& Scottish Law Commission 2018, nr. 3.6 e.v. en bijlage 3 (hierna: Law Commission \& Scottish Law Commission 2018). 
en uitrustingsstukken van oudsher een prominente rol. Voertuigen en onderdelen daarvan moeten aan een groot aantal technische voorschriften voldoen alvorens te worden toegelaten tot de handel of het verkeer. Door de jaren heen is er op dit terrein een zeer omvangrijke hoeveelheid wetgeving tot stand gekomen, die voor de belangrijkste categorieën motorrijtuigen in Europa volledig is geharmoniseerd. Richtlijn 2007/46/EG ${ }^{17}$ voorziet in een Europese typegoedkeuring(sprocedure): goedkeuring in één EU-lidstaat leidt tot toelating in de gehele Europese Unie. ${ }^{18}$ Deze kaderrichtlijn verwijst voor de concrete constructie- en prestatienormen ten aanzien van de verschillende aspecten van motorrijtuigen, alsmede de voorgeschreven testprocedures, naar aparte richtlijnen en verordeningen, die in dit verband 'bijzondere' richtlijnen of verordeningen worden genoemd. Voorts wordt in de richtlijnen in toenemende mate verwezen naar VN/ECE-reglementen. Het betreft hier pan-Europese normen die onder auspiciën van de VN in Genève tot stand komen. Voor zover de Europese Unie die reglementen heeft aanvaard, maken deze op dezelfde wijze als de bijzondere richtlijnen of verordeningen deel uit van de EU-typegoedkeuring voor voertuigen.

De huidige technologische ontwikkelingen stellen het bestaande reguleringskader op de proef. ${ }^{19}$ Gesteld kan worden dat het bestaande wettelijk instrumentarium, dat is afgestemd op de traditionele 'mechanische' auto, onvoldoende is toegesneden op de ontwikkeling van de auto naar een 'computer op wielen', die in groeiende mate al dan niet onder supervisie van een menselijke bestuurder autonoom opereert. ${ }^{20}$ Knelpunten houden meer specifiek verband met de volgende vier factoren.

1. De snelheid van de technologieontwikkeling.

De ontwikkelingen op het terrein van voertuigautomatisering gaan snel en zijn gevarieerd. Het opstellen van daarop afgestemde wettelijke veiligheidsnormen is daarentegen een langdurig proces. Het door rechtsstatelijke eisen, zoals democratische besluitvormingsprocedures, geconditioneerde wetgevingsproces neemt doorgaans veel tijd in beslag, met name op internationaal niveau. ${ }^{21}$ Het verleent aan deze voorschriften enerzijds een democratische legitimatie, maar staat anderzijds een flexibel inspelen op technologische ontwikkelingen in de weg.

Niet onbelangrijk in dit verband is dat Richtlijn 2007/46/EG in een ontheffingsmogelijkheid voorziet die enige flexibiliteit beidt. Op verzoek van de fabrikant kan goedkeuring worden verleend aan systemen, onderdelen of technische eenhe-

17 Richtlijn van 9 oktober 2007 tot vaststelling van een kader voor de goedkeuring van motorvoertuigen en aanhangwagens daarvan en van systemen, onderdelen en technische eenheden die voor dergelijke voertuigen zijn bestemd (PbEG 2007, L 263, p. 1 e.v.).

18 De aanvraag voor een typegoedkeuring wordt door de fabrikant ingediend bij de bevoegde goedkeuringsinstantie. In Nederland is dat de RDW.

19 Onderzoeksraad voor Veiligheid 2019, p. 63 e.v. (hoofdstuk 4); K.A.P.C. van Wees, 'Intelligente voertuigen, veiligheidsregulering en aansprakelijkheid', TRAIL 2004, p. 43 e.v. (hoofdstuk 2); en voor de VS: S.A. Mathews, 'When Rubber Meets the Road: Balancing Innovation and Public Safety in the Regulation of Self-Driving Cars', Boston College Law Review (61) 2020, p. 295-338. Onderzoeksraad voor Veiligheid 2019, p. 68. 
den waarin technologieën of concepten zijn toegepast die onverenigbaar zijn met één of meer van de bestaande voorschriften (art. 20 Richtlijn). ${ }^{22}$ Met deze ontheffingsmogelijkheid kan worden voorkomen dat bestaande technische voorschriften een onwenselijke belemmering gaan vormen voor innovatie. Als voorwaarde geldt dat uit tests moet blijken dat in vergelijking met de voorschriften waarvan ontheffing wordt aangevraagd, ten minste een even hoog veiligheidsniveau wordt gewaarborgd. Een toelating op basis van deze ontheffingsgrond is in afwachting van vergunningverlening door de Commissie slechts geldig voor het grondgebied van de lidstaat waar het voertuig ter goedkeuring is aangeboden. Wordt deze vergunning verleend, dan neemt de Commissie de nodige stappen om de desbetreffende bijzondere richtlijnen of verordeningen aan de technologische ontwikkelingen aan te passen.

Hoewel deze ontheffingsmogelijkheid dus enige flexibiliteit biedt en kan voorkomen dat bestaande regelgeving een hinderlijke belemmering vormt voor nieuwe veiligheidsverhogende technologie, kan zij de behoefte aan specifieke, op de nieuwe technologie afgestemde veiligheidsnormen niet wegnemen. Als specifieke eisen niet voorhanden zijn (of niet scherp genoeg), kan onduidelijkheid ontstaan over welke toelatingseisen van toepassing zijn op nieuw te introduceren rijtaakautomatiserende systemen en in hoeverre deze een belemmering vormen, en dus slechts via een (met enige waarborgen omgeven en tot aanpassing van de regels leidende) ontheffingsprocedure kunnen worden toegelaten. Dat kan worden geïllustreerd aan de hand van de gang van zaken bij de goedkeuring van de eerste SAE-niveau-2-systemen, zoals de Autopilot van Tesla. In Nederland werd het systeem binnen de bestaande toelatingseisen goedgekeurd, terwijl in Duitsland een artikel-20-procedure werd gestart, omdat de betreffende goedkeuringsinstantie vond dat het nieuwe systeem niet binnen de bestaande regelgeving paste. $^{23}$

2. Gebrek aan expertise bij de overheid.

Voertuigautomatisering neemt nieuwe, eigensoortige risico's met zich mee. De betrokkenen bij het opstellen en toepassen van 'klassieke' voertuigeisen ontbreekt het aan specifieke kennis ten aanzien van deze nieuwe risicodomeinen. ${ }^{24}$ Er zal dus expertise moeten worden ontwikkeld op terreinen als mens-machineinteractie en softwareveiligheid. Bovendien brengt de complexiteit van de technologie mee dat alleen deskundigen nog in staat zijn inhoud te geven aan de relevante veiligheidsnormen. De overheid neemt niet zelf deel aan het ontwikke-

22 Voorts biedt art. 29 van de Richtlijn lidstaten de mogelijkheid om nieuwe voertuigen, systemen, onderdelen of technische eenheden, ook al voldoen zij aan de toepasselijke voorschriften, gedurende maximaal zes maanden te weigeren te registreren dan wel de verkoop of het in verkeer brengen van deze voertuigen, systemen, onderdelen of technische eenheden op zijn grondgebied toe te staan, ingeval zij naar het oordeel van de lidstaat een ernstig gevaar betekenen voor de verkeersveiligheid.

23 Onderzoeksraad voor Veiligheid 2019, p. 69. Dergelijke discussies deden zich in een verder verleden ook voor met betrekking tot systemen als Adaptive Cruise Control en ESP. Zie Van Wees 2004, p. 84.

24 Onderzoeksraad voor Veiligheid 2019, p. 96. Law Commission \& Scottish Law Commission 2018, nr. 4.48 . 
lingsproces. Het gevaar dreigt dan ook dat het de overheid in toenemende mate zal ontbreken aan de vereiste deskundigheid om met gezag preventief normerend op te treden. In ieder geval kan worden vastgesteld dat, hoewel inmiddels de nodige initiatieven zijn gestart om regels op te stellen voor rijtaakautomatiserende systemen, tot op heden nauwelijks eisen zijn ontwikkeld op gebieden als mens-machine-interactie, softwarekwaliteit en cybersecurity. ${ }^{25}$ Daardoor worden nieuwe risico's niet voldoende meegewogen in de beslissing om een bepaald voertuig of specifieke systemen toe te laten.

\section{Aard van de technologie vraagt om ander type normering.}

Ook de veranderende aard van de technologie roept de vraag op of adequaat kan worden ingespeeld op de technologische ontwikkelingen. Zo leent de bestaande benadering, waarin per aspect of onderdeel van een voertuig technische eisen zijn opgesteld, zich slecht voor de beoordeling van complexe voertuigelektronica waarvan het functioneren veelal betrekking heeft op meer dan één aspect of onderdeel. Een meer integrale beoordeling is hier gewenst. Ook leent de technologie zich steeds minder voor het stellen van objectief meetbare prestatie-eisen. Welke prestatie-eisen kan men in dit verband stellen aan software? De aard van de technologie brengt met zich mee dat men meer en meer zijn toevlucht zal moeten nemen tot (meer subjectieve) ontwerpprocesnormen en alternatieve scenariogebaseerde simulatietests zal moeten ontwikkelen. ${ }^{26}$

\section{Veranderingen tijdens de levensduur.}

Moderne auto's met rijtaakautomatiserende systemen beschikken vrijwel allemaal over de mogelijkheid om draadloos te communiceren met bijvoorbeeld de fabrikant, waarmee het updaten van software gemakkelijker is geworden ('over the air updates'). Automatiseringssystemen kunnen tijdens de levensduur van de auto zodoende regelmatig worden geüpdatet om eventuele bugs of kwetsbaarheden op te lossen. Ook kan de functionaliteit worden uitgebreid of bijgesteld. ${ }^{27}$ Deze updates worden niet vooraf beoordeeld en getoetst door de toezichthouder, want het toelatingskader strekt zich vooralsnog niet uit tot latere softwarewijzigingen. ${ }^{28}$

Dit soort aspecten roepen vanzelfsprekend de vraag op hoe het publiekrechtelijk instrumentarium beter kan worden afgestemd op de ontwikkelingen rond voertuigautomatisering. Inmiddels kan worden gewezen op een aantal initiatieven om bovenstaande knelpunten te adresseren. Zo zijn richtlijnen opgesteld omtrent de toepassing van de ontheffingsmogelijkheid (art. 20-procedure) in relatie tot rij-

Zie voor een kort overzicht van de stand van zaken Onderzoeksraad voor Veiligheid 2019, p. 70-71 en 152-155.

26 Law Commission \& Scottish Law Commission 2018, nr. 4.47.

27 Zo meldt Tesla op haar website en in radiocommercials dat elke nieuwe Tesla beschikt over de hardware om de auto in de toekomst volledig autonoom te laten rijden. Van bijstelling was sprake toen Tesla, na een dodelijk ongeval in Florida in 2016, een draadloze software-update uitvoerde die erin voorzag dat de autopilot meer gebruik maakt van radar, en dat bepaalde maatregelen werden doorgevoerd die ervoor moeten zorgen dat bestuurders meer bij de les blijven. 
taakautomatiserende systemen ${ }^{29}$ en wordt de Commissie in de onlangs aangenomen General Safety Regulation opgedragen om met specifieke voorschriften voor geautomatiseerde voertuigen te komen om de verkeersveiligheid te waarborgen. ${ }^{30}$ Voorts wordt het bestaande systeem van typegoedkeuringen door de nieuwe Europese kaderverordening (EU) 2018/858, ${ }^{31}$ die de huidige kaderrichtlijn 2007/46/EG per 1 september 2020 gaat vervangen, op verschillende punten aangescherpt. Zo worden er strengere eisen gesteld aan (onder de verantwoordelijkheid van de) nationale typegoedkeuringsinstanties (vallende technische diensten) en worden deze onderworpen aan toetsing door de Commissie om ervoor te zorgen dat de toepasselijke regels uniform worden toegepast en gehandhaafd, wordt de informatie-uitwisseling tussen goedkeuringsinstanties verbeterd en worden lidstaten verplicht middels periodieke steekproeven te controleren of voertuigen nog steeds aan de voorschriften voldoen.

Het zal evenwel helder zijn dat een adequate afstemming van het reguleringskader op de toekomstige introductie van de zelfrijdende auto een verdergaande herziening van het instrumentarium zal vergen. ${ }^{32}$ Voorts roepen bovenstaande bevindingen de vraag op - en daarmee raken we aan het onderwerp van dit themanummer - welke rol het privaatrecht, meer in het bijzonder het aansprakelijkheidsrecht, kan spelen om als (aanvullende) vorm van veiligheidsregulering te fungeren. In de volgende paragraaf zal daarop nader worden ingegaan.

\section{Aansprakelijkheid voor rijtaakautomatiserende systemen}

In het aansprakelijkheidsrecht draait het in hoofdzaak om de vraag wie voor de ontstane schade aansprakelijk kan worden gesteld en deze moet vergoeden. ${ }^{33}$ De regels van het aansprakelijkheidsrecht bepalen onder welke omstandigheden men recht heeft op vergoeding. De ontwikkeling van de rijtaakautomatiserende systemen roept in dit verband nieuwe vragen op. Wie is aansprakelijk als er onverhoopt iets misgaat? Zal aansprakelijkheid voor verkeersongevallen verschuiven

29 Guidelines on the Exemption Procedure for the EU Approval of Automated Vehicles (zie https:// ec.europa.eu/docsroom/documents/34802).

30 Art. 11 van Verordening (EU) 2019/2144 van 16 december 2019 betreffende de voorschriften voor de typegoedkeuring van motorvoertuigen en aanhangwagens daarvan en van systemen, onderdelen en technische eenheden die voor dergelijke voertuigen zijn bestemd wat de algemene veiligheid ervan en de bescherming van de inzittenden van voertuigen en kwetsbare weggebruikers betreft (PbEU 2019, L 325, p. 1 e.v.).

31 Verordening (EU) 2018/858 van 14 juni 2018 betreffende de goedkeuring van en het markttoezicht op motorvoertuigen en aanhangwagens daarvan en systemen, onderdelen en technische eenheden die voor dergelijke voertuigen zijn bestemd (PbEU 2018, L 151, p. 1 e.v.).

32 Zie op dit punt bijv. de voorstellen van de Engelse en Schotse Law Commissions (Law Commission \& Scottish Law Commission 2018, nr. 4.123 e.v.) en (meer beleidsmatig) de aanbevelingen van de Onderzoeksraad voor Veiligheid (Onderzoeksraad voor Veiligheid 2019, p. 91).

33 Naast schadevergoeding kent het aansprakelijkheidsrecht echter nog andere remedies, zoals een verklaring voor recht en het rechterlijk verbod of bevel (art. 3:296 BW). 
naar autofabrikanten en systeemproducenten? Voorziet het bestaande aansprakelijkheidsrecht in een maatschappelijk bevredigende toedeling van risico's? ${ }^{34}$

Het antwoord op de laatste vraag is impliciet tevens een vraag naar de functies van het aansprakelijkheidsrecht. Immers, de eventuele vaststelling dat het aansprakelijkheidsrecht tekortschiet, kan moeilijk los worden gezien van de doelen die met het aansprakelijkheidsrecht worden nagestreefd. Compensatie en preventie worden van oudsher als belangrijkste doelstellingen genoemd. ${ }^{35}$

Een preventieve (of regulerende) werking van het aansprakelijkheidsrecht zou in de eerste plaats kunnen worden gezocht in het feit dat rechters op basis van de open normen van het aansprakelijkheidsrecht bepaalde zorgplichten formuleren. Uitspraken van rechters geven zodoende vorm en invulling aan wat van maatschappelijke spelers zoals producenten wordt verwacht in termen van omgaan met risico's. ${ }^{36}$ Daarnaast kan de wetenschap schadevergoeding te moeten betalen indien schade aan derden wordt toegebracht, aanzetten tot het nemen van maatregelen om die schade te voorkomen. ${ }^{37}$ Meer indirect kan het aansprakelijkheidsrecht nog tot het terugdringen van ongevallen leiden, doordat via het aansprakelijkheidsrecht ongevalskosten worden doorberekend aan een bepaalde activiteit, en dit zodoende invloed zal hebben op het activiteitenniveau (hoe gevaarlijker een activiteit, hoe hoger immers de kostprijs van die activiteit zal zijn).

Over de vraag in hoeverre het aansprakelijkheidsrecht in de praktijk daadwerkelijk een dergelijke preventieve werking heeft of kan hebben, lopen de meningen

34 Zie voor nadere besprekingen van (en enigszins wisselende antwoorden op) deze vragen A.I. Schreuder, 'Aansprakelijkheid voor “zelfdenkende” apparatuur', AV\&S 2014, p. 131-136; N.E. Vellinga, 'De civielrechtelijke aansprakelijkheid voor schade veroorzaakt door een autonome auto', VR 2014, p. 151 e.v.; K.A.P.C. van Wees, 'Aansprakelijkheidsaspecten van (deels) zelfrijdende auto's', AV\&S 2015, p. 170-180; T.F.E. Tjong Tjin Tai \& S. Boesten, 'Aansprakelijkheid, zelfrijdende auto's en andere zelfbesturende objecten', NJB 2016, p. 656-664; E. Engelhard, 'Wetgever, pas op! De (vrijwel) autonome auto komt eraan', AA 2017, p. 230-236; N. Lavrijssen \& M. Weitering, 'De zelfrijdende auto en het overmachtsverweer van art. 185 WVW', VR 2019, p. 167-171.

35 A.J. Verheij, Onrechtmatige daad (Monografieën Privaatrecht 4), Deventer: Wolters Kluwer 2019, p. 14. Overigens is de kwalificatie van compensatie als doelstelling van het aansprakelijkheidsrecht problematisch. Compensatie is geen doel op zich, het gaat erom te bepalen in welke gevallen recht bestaat op compensatie (en dus ook in welke gevallen niet). Het is wellicht beter in dit verband, in navolging van C. Van Dam, te spreken van de doelstelling van herstel van geschonden rechten en belangen. Waar schade het resultaat van de schending van een recht of belang is, is schadevergoeding de belangrijkste remedie voor het herstellen van dit recht of belang. Zie in dit verband C. van Dam, Aansprakelijkheidsrecht, Den Haag: Boom juridisch 2020, nr. 102-3.

36 E.R. de Jong, 'Rechterlijke risicoregulering: over de veranderende publieke rol van de civiele rechter bij gezondheids- en milieurisico's', RMThemis 2020, p. 10; E.R de Jong, M.G. Faure, I. Giesen \& P. Mascini, 'Judge-made Risk Regulation and Tort Law: An Introduction', European Journal of Risk Regulation (9) 2018, p. 6-13, hier p. 8.

37 L.T. Visscher, Een rechtseconomische analyse van het Nederlandse onrechtmatigedaadsrecht, Den Haag: Boom Juridische uitgevers 2005, p. 17. 
overigens danig uiteen. ${ }^{38}$ Uit het weinige beschikbare onderzoek kunnen geen eenduidige conclusies worden getrokken. ${ }^{39}$

Voor de mate waarin aansprakelijkheid kan bijdragen aan het voorkomen van ongevallen lijkt in ieder geval de aard van de gesanctioneerde gedraging van belang te kunnen worden geacht. ${ }^{40} \mathrm{Bij}$ routinematige handelingen of gedragingen waarbij voortdurende concentratie en 'split second'-beslissingen worden vereist, zoals bij het besturen van een auto, zal veel minder preventief effect te verwachten zijn dan bij activiteiten waarbij van tevoren in alle rust over de veiligheid kan worden nagedacht, zoals bij het ontwerpen en 'vermarkten' van rijtaakautomatiserende systemen.

\subsection{Productaansprakelijkheid}

Autoproducenten worden tot op heden zelden aangesproken op basis van productaansprakelijkheid, maar dat zal bij de grootschalige toepassing van autonome systemen danig kunnen veranderen. Immers, de eigenschappen en het functioneren van het voertuig zullen dan in verhouding een steeds grotere rol spelen als oorzaak van - naar verwachting overigens een dalend aantal - verkeersongevallen.

De producent is op basis van artikel 6:185 van het Burgerlijk Wetboek (BW) aansprakelijk indien schade wordt veroorzaakt door een gebrek in zijn product. ${ }^{41}$ Of hem een verwijt treft, doet in beginsel niet ter zake. Wel kan de producent mogelijk een beroep doen op een van de limitatief opgesomde verweren, waaronder het zogenoemde ontwikkelingsrisicoverweer (het gebrek was naar de stand van de techniek en wetenschap ten tijde van het op de markt brengen van het product onmogelijk te ontdekken). ${ }^{42}$

Kernvereiste voor aansprakelijkheid is de aanwezigheid van een gebrek. Van een gebrek is sprake als, alle omstandigheden in aanmerking genomen, het product niet de veiligheid biedt die men ervan mag verwachten (art. 6:186 BW). Aansprakelijkheid beperkt zich dus niet tot gebreken als gevolg van incidentele uitglijders in het productieproces (productiegebreken), maar kan ook betrekking hebben op een onveilig ontwerp als zodanig (ontwerpgebreken) of een gebrekkige presentatie (presentatiegebreken). ${ }^{43}$ Met name deze laatste mogelijkheid, de mogelijkheid dat een rechter een product gebrekkig kan oordelen wegens een

38 Visscher 2005, p. 16-17.

39 M.G. Faure, 'Economic Analysis of Product Liability', in: P. Machnikowski (red.), European Product Liability. An Analysis of the State of the Art in the Era of New Technologies, Antwerpen: Intersentia 2016, p. 619-665, hier p. 652-653; Visscher 2005, p. 288.

40 C. van Dam 2020, nr. 103-1.

41 De in afd. 6.3.3 BW vastgelegde regeling is gebaseerd op de Europese richtlijn productaansprakelijkheid (Richtlijn 85/374/EEG, PbEG 1985, L 210/29).

42 Zie art. 6:185 lid 1 BW ('tenzij ...').

43 Bij aansprakelijkheid voor ontwerp- en presentatiegebreken gaat het, anders dan voor productiegebreken, niet om een (zuivere) risicoaansprakelijkheid, maar in essentie om de toepassing van (strenge) zorgvuldigheidsnormen in de vorm van onderzoeks-, anticipatie-, informatie-, instructie-, productbewakings- en recall-verplichtingen. 
onvoldoende veilig ontwerp, een misleidende presentatie of tekortschietende instructies, kan producenten aanzetten tot het nemen van voorzorgsmaatregelen om ongevallen te voorkomen. Bovendien wordt het belang van deze privaatrechtelijke veiligheidsregulering groter voor zover publiekrechtelijke veiligheidseisen (nog) ontbreken. ${ }^{44}$ Vanuit preventief oogpunt lijkt het dan ook wenselijk dat de rechter niet te gemakkelijk het verweer van de producent honoreert dat de automobilist eigen schuld aan het ongeval heeft. ${ }^{45}$ Dit zal producenten immers aanzetten om op eventuele risico's te anticiperen in de sfeer van het ontwerp en de presentatie van rijtaakautomatiserende systemen. Zo kan men het functioneren van het systeem beperken tot 'veilige' snelheden en/of wegcategorieën (geofencing) of bepaalde ontwerpmaatregelen nemen die erop gericht zijn de bestuurder voldoende 'in the loop' te houden (de 'autopilot' schakelt uit zodra de bestuurder meer dan enkele seconden zijn handen van het stuur haalt of zijn ogen te veel van het verkeer afwendt). ${ }^{46}$

Anderzijds kan worden geconstateerd dat toepassing van het gebrekscriterium op rijtaakautomatiserende systemen vanuit preventief perspectief niet steeds onproblematisch is. Een belangrijk probleem lijkt te schuilen in het volgende: beperkingen van de techniek kunnen meebrengen dat een dergelijk systeem - dat in zijn algemeenheid verkeersongevallen helpt voorkomen - een enkele keer een ongeval veroorzaakt dat een bestuurder van vlees en bloed had kunnen (en moeten) vermijden. ${ }^{47}$ Met andere woorden: bij de huidige stand van de techniek zal een (deels) zelfrijdende auto niet onder alle omstandigheden aan de menselijkebestuurdermaatstaf kunnen voldoen. De vraag is dan of dit een gebrek in de zin

44 Voor zover dit ontbreken valt terug te voeren op een gebrek aan kennis over de risico's, zal ook de rechter zich met deze onzekerheid geconfronteerd zien, alsmede met de lastigheid dat de kosten en de baten van een bepaald systeem, en de in beschouwing te nemen alternatieven, hooguit bij benadering kunnen worden gewogen. Dat betekent echter niet dat de rechter zich dan maar zou moeten onthouden van een oordeel. Wel mogen we van de rechter verwachten dat hij zich zo goed mogelijk laat informeren door onafhankelijke deskundigen, en dat hij zodanig motiveert dat duidelijk is wat er geëist wordt. Zie W.H. van Boom, Structurele fouten in het aansprakelijkheidsrecht (oratie Tilburg), Den Haag: Boom Juridische uitgevers 2003, p. 34.

45 Zie in dit verband E. Awad e.a., 'Drivers Are Blamed More Than Their Automated Cars When Both Make Mistakes', Nature Human Behaviour 2020, p. 134-143.

46 Fabrikanten hanteren op dit punt verschillende strategieën. Na het fatale ongeval met een Tesla in Florida heeft deze fabrikant een update doorgevoerd die maakt dat de autopilot zich automatisch uitschakelt als een bestuurder zijn handen gedurende langere tijd van het stuur haalt en het alarm dat de chauffeur hierop wijst, besluit te negeren. Het systeem kan door de chauffeur pas weer worden aangezet als hij de auto uit- en aanzet. GM maakt ook gebruik van sensoren die de ogen en het gezicht van de bestuurder in de gaten houden. Zie A.B. Lemann, 'Autonomous Vehicles, Technological Progress, and the Scope Problem in Products Liability', Journal of Tort Law (12) 2019, afl. 2, p. 157-212, hier p. 168-169. Werbrouck (J. Werbrouck, 'De productaansprakelijkheid voor zelfrijdende motorrijtuigen', TPR 2018, p. 529-603) bespreekt in dit verband ook een eventuele anticipatieplicht inzake het ongewenst overnemen van de besturing in situaties waarin dat gevaarlijk is (nr. 49) en gebruik door dronken bestuurders (nr. 44 e.v.). 
van artikel 6:186 BW oplevert, waarvoor de producent aansprakelijk is, ${ }^{48}$ of dat deze niet (of bezwaarlijk) te vermijden risico's op de koop toe genomen dienen te worden met een beroep op de evidente voordelen van de techniek, en om die reden geen gebrekkig product opleveren in de zin van artikel 6:186 BW. ${ }^{49}$

Hamvraag is dan of de producent zich zal kunnen verweren met een beroep op de state of the art, of dat er een strengere norm dient te gelden, neerkomende op de menselijke-bestuurdermaatstaf, waarmee bedoeld wordt dat de zelfrijdende auto zich qua rijgedrag in elke omstandigheid zou moeten kunnen meten met een zorgvuldige menselijke bestuurder? Voor zover het rijtaakautomatiserende systemen betreft die niet langer van de bestuurder verlangen dat hij continu de weg- en verkeerscondities monitort om eventuele tekortkomingen van het systeem op te vangen (SAE-automatiseringsniveaus 3, 4 en 5), of voor zover de gebruiker niet de mogelijkheid had om door zorgvuldig gebruik het risico te vermijden, lijken 'schadelijke bijwerkingen' minder acceptabel. Het toerekenen van dergelijke bijwerkingen aan de producent lijkt aan te sluiten bij de basisgedachte van de productaansprakelijkheidsrichtlijn om juist het toevallige slachtoffer van een gebrekkig product te beschermen. Verdedigd kan worden dat het gebreksbegrip van de richtlijn daar ook de nodige ruimte toe biedt. ${ }^{50}$ Anderzijds wordt tegengeworpen dat een dergelijke slachtoffervriendelijke interpretatie te zeer een belemmering vormt om rijtaakautomatiserende systemen op de markt te brengen, waardoor de maatschappelijke voordelen van deze systemen onvoldoende benut zouden worden. ${ }^{51}$

Voor een cijfermatige concretisering van dit vraagpunt kan worden verwezen naar Amerikaans onderzoek, waarin wordt berekend dat op de korte en de lange termijn in de Verenigde Staten aanzienlijk meer mensenlevens zouden worden gespaard (tot wel meer dan een half miljoen) als volledig zelfrijdende auto's geaccepteerd zouden worden die slechts $10 \%$ veiliger presteren dan menselijke bestuurders, dan als deze pas zouden worden toegelaten als dit percentage op

48 Iets anders is natuurlijk welke risico's aanvaardbaar geacht kunnen worden in het kader van de publiekrechtelijke toelating van dit soort systemen. Daarbij kunnen ook ethische vragen rijzen. Mag een zelfrijdende auto bijv. steeds de belangen van de eigen inzittenden vooropstellen als een ongeval onvermijdelijk is? Zie over dit type vragen o.a. het rapport van de Ethik-Kommission Automatisiertes und Vernetztes Fahren: Bericht Juni 2017, Bundesministerium für Verkehr und digitale Infrastruktur.

49 Hoewel art. 6 van de richtlijn en art. 6:186 BW geen expliciete verwijzing naar een afweging van de voor- en nadelen kennen, kan worden aangenomen dat onder het richtlijnregime wel ruimte bestaat voor een dergelijke afweging. Er wordt immers verwezen naar gerechtvaardigde verwachtingen, waarbij alle omstandigheden in beschouwing worden genomen. Vgl. D. Wuyts, 'The Product Liability Directive - More Than Two Decades of Defective Products in Europe', Journal of European Tort Law (5) 2014, afl. 1, p. 11-12.

50 Van Wees 2018, p. 120.

51 Zie bijv. M. Schellekens, 'Self-driving Cars and the Chilling Effect of Liability Law', Computer Law \& Security Review 2015, p. 506-517; J. Tanghe \& J. de Bruyne, 'Liability for Damage Caused by Autonomous Vehicles: A Belgian Perspective', Journal of European Tort Law (8) 2018, afl. 3, p. 368-369. 
minstens $75 \%$ ligt. Het onderzoek concludeert dan ook dat de maatschappelijke kosten van het wachten op de perfecte zelfrijdende auto hoog zijn. ${ }^{52}$

\subsection{Het alternatief van de directe verzekering (verkeersverzekering)}

De hierboven geïdentificeerde (potentiële) problemen bij de toepassing van de bestaande productaansprakelijkheidsregels op rijtaakautomatiserende technologie (enerzijds de mogelijkheid dat 'toevallige' slachtoffers met lege handen blijven staan; anderzijds een mogelijk 'chilling effect' op de ontwikkeling en introductie van technologie die de verkeersveiligheid substantieel kan verbeteren) zetten aan tot nadenken over mogelijke alternatieven.

Een potentieel alternatief dat steeds meer bijval krijgt, is dat van de directe verzekering, ook wel verkeersverzekering genoemd. ${ }^{53} \mathrm{Bij}$ een stelsel van directe (verkeers)verzekering wordt de automobilist ${ }^{54}$ verplicht een verzekering te sluiten die de schade - daarbij wordt meestal aan een beperking tot letselschade gedacht dekt van de inzittenden van het eigen voertuig, onder wie in beginsel ook de bestuurder zelf, alsmede de schade die ongemotoriseerden lijden als gevolg van een ongeval. ${ }^{55}$ Uitkering is niet afhankelijk van het kunnen aanwijzen van een aansprakelijke derde, maar van de vraag of schade is geleden als gevolg van een verkeersongeval (of meer precies: het zich voordoen van het in de polis omschreven verkeersrisico). ${ }^{56}$ Bij een ongeval claimt ieder slachtoffer bij de verzekeraar van het motorrijtuig waarin hij zich bevond. ${ }^{57}$ Lastige aansprakelijkheidsdiscus-

52 N. Kalra \& D. Groves, The Enemy of Good. Estimating the Cost of Waiting for Nearly Perfect Automated Vehicles, Santa Monica, CA: RAND 2017, p. 3. Aan de andere kant is het evident dat de acceptatie van risico's niet enkel bepaald wordt door absolute aantallen doden en gewonden. Technisch falen van een zelfrijdende auto wordt nu eenmaal anders gewaardeerd dan een traditionele menselijke bestuurdersfout.

53 K.A.P.C. van Wees, 'Zelfrijdende auto's, aansprakelijkheid en verzekering. Over nieuwe technologie en oude discussies', TVP 2016, p. 29-34.

54 Aansluiting zou kunnen worden gezocht bij de verzekeringsplichtige van de WAM, te weten (in uitgangspunt) de bezitter of houder van het voertuig (zie art. 2 WAM).

55 Een dergelijk systeem bestaat bijv. in Zweden. Zie voor een bespreking S. Friberg \& B.W. Dufwa, 'The Development of Traffic Liability in Sweden', in: W. Ernst (red.), The Development of Traffic Liability, Cambridge: Cambridge University Press 2014, p. 190-227, hier p. 203 e.v.

56 Bestaande vormen van directe verzekeringen voor verkeersschade zijn de op vrijwillige basis af te sluiten Ongevallenverzekering inzittenden (OVI) en Schadeverzekering inzittenden (SVI). Voorts heeft de Hoge Raad in een reeks van arresten geoordeeld dat de norm van goed werkgeverschap van art. 7:611 BW meebrengt dat de werkgever ten aanzien van zijn werknemers die in het kader van hun werkzaamheden aan het verkeer deelnemen een first-partyverzekering dient af te sluiten, die dekking biedt bij verkeersongevallen. In dit verband wordt ook wel over een 'verplichte' verzekering gesproken, maar van een rechtstreeks op de wet gebaseerde verplichting is geen sprake.

57 Deze first-partydekking zou als een nieuw element aan de verplichte dekking van de WAM kunnen worden toegevoegd. 
sies doen zich daarbij in beginsel niet meer voor. ${ }^{58}$ Alle slachtoffers van een ongeval met een zelfrijdende auto krijgen op relatief eenvoudige wijze hun schade vergoed.

In een onlangs voor het Europees Parlement verricht onderzoek wordt geconcludeerd dat een 'no fault insurance framework' de beste mogelijkheden biedt om de aansprakelijkheidsvraagstukken rond (deels) zelfrijdende auto's het hoofd te bieden. ${ }^{59}$ In het Verenigd Koninkrijk werd in 2018 de Automated and Electric Vehicle Act aangenomen, die feitelijk een systeem van verkeersverzekering in het leven roept voor schade veroorzaakt door zelfrijdende auto's. ${ }^{60}$ Ook in ons land vormt de opkomst van de zelfrijdende auto een reden om serieus na te denken over een stelsel van directe verzekering als alternatief voor het bestaande aansprakelijkheidsrecht. Eind 2015 werd de discussie over de first-partyverzekering voor verkeersongevallen nieuw leven ingeblazen toen het Verbond van Verzekeraars aankondigde de mogelijkheid te onderzoeken van een verkeersverzekering, die de risico's verbonden aan het gemotoriseerd verkeer zou moeten gaan dekken. ${ }^{61}$ In het recent door het Verbond van Verzekeraars uitgebrachte middellangetermijnplan 2019-2021 (MLT) valt te lezen dat aan de uitwerking van het concept van een directe verzekering 'absolute prioriteit' zal worden gegeven. ${ }^{62}$

Op het eerste gezicht zou men kunnen denken dat een dergelijke systeemwijziging - van aansprakelijkheid naar directe verzekering - vanuit preventief oogpunt minder wenselijk is. Immers, dat zal ertoe leiden dat de producent of ontwikkelaar, die feitelijk de meeste invloed heeft op het veilig functioneren van de rijtaakautomatiserende systemen, in beginsel buiten schot blijft. Het slachtoffer zal zijn schade op eenvoudige wijze door de verzekeraar van het 'eigen' voertuig vergoed krijgen en zal zich zodoende de moeizame(re) weg van een schadeclaim jegens de producent kunnen besparen. Dat men middels een verkeersverzekering voorziet in ruime en soepele vergoeding van verkeersschade aan de directe slachtoffers hoeft echter nog niet te betekenen dat in een dergelijk stelsel de veroorzaker civielrechtelijke immuniteit geniet. De verzekeraar van het voertuig zou op zijn beurt weer verhaal kunnen halen op degene die op basis van het aansprakelijk-

58 Het feit dat niet langer gediscussieerd hoeft te worden over de grondslag van aansprakelijkheid betekent evenwel niet dat er geen discussie kan ontstaan over andere juridische vraagpunten, zoals over het causaal verband tussen ongeval en schade en een eventuele vermindering van de vergoeding op basis van eigen schuld. Veel zal in dit verband afhangen van de precieze vormgeving van een dergelijk stelsel.

59 T. Evas, A Common EU Approach to Liability Rules and Insurance for Connected and Autonomous Vehicles, European Parliamentary Research, februari 2018, p. 5-6.

60 Zie www.legislation.gov.uk/ukpga/2018/18/contents/enacted. Zie voor een bespreking R. de Bruin, 'De Automated and Electric Vehicles Act. Een Britse oplossing voor aansprakelijkheidsvraagstukken rondom autonome(re) auto's', NJB 2020/687.

61 Verbond van Verzekeraars, Toekomstvisie Automotive. Onderweg naar morgen, 2015. Overigens spelen hier voor verzekeraars ook andere motieven een rol, zoals het willen inspelen op de ontwikkeling van nieuwe, steeds minder op privébezit gestoelde, vormen van autogebruik (zie Verbond van Verzekeraars 2015, p. 6).

62 Verbond van Verzekeraars, MLT 2019-2021. Nieuwe wegen, par. 1.19. Zie www.verzekeraars.nl/ media/5599/interactief-beleidsplan-mlt-2019-2021.pdf. 
heidsrecht aansprakelijk is. De aansprakelijkheidsdiscussie vindt dan plaats in het kader van het onderling verhaal tussen verzekeraars en wordt aldus verschoven naar de achterkant van het stelsel, waarbij omwille van de kosten afwikkeling vanzelfsprekend niet op dossierniveau hoeft plaats te vinden, terwijl de kostenallocatie conform het aansprakelijkheidsrecht in stand zou kunnen blijven. ${ }^{63}$

Voorts is vanuit een oogpunt van preventie van belang dat een bijkomend voordeel van een directe verzekering, waarbij de verzekeraar de schade van (de inzittenden van) het eigen motorrijtuig dekt, is dat de verzekeraar effectiever veiligheidsverhogende maatregelen kan stimuleren dan een verzekeraar die de schade van (de inzittenden van) een aangereden voertuig dekt. First-partyverzekeraars hebben meer dan aansprakelijkheidsverzekeraars een direct financieel belang bij het middels hun acceptatiebeleid en premiestelling stimuleren van de aanschaf van veilige(r) voertuigen of het bevorderen van een veiliger rijgedrag. Daarbij is niet alleen van belang dat rijtaakautomatiserende systemen potentieel een belangrijke bijdrage kunnen leveren aan de verkeersveiligheid, maar ook dat de technologie geheel nieuwe mogelijkheden biedt om het gedrag van bestuurders te monitoren en daarop de premie aan te passen ('pay as you drive'-verzekeringen). ${ }^{64}$ Vanuit een oogpunt van preventie heeft een aan het bezit van een voertuig gekoppelde directe verzekering in potentie dus betere papieren dan een aansprakelijkheidsverzekering.

\section{Slot}

Samenvattend kan worden gesteld dat van aansprakelijkheid, althans in theorie, een preventieve werking kan uitgaan en dat aansprakelijkheidsrecht zodoende een aanvullende werking kan hebben op publiekrechtelijke veiligheidswetgeving, met name bij nieuwe technologische toepassingen zoals rijtaakautomatiserende systemen, waar het nog in belangrijke mate aan veiligheidsnormen ontbreekt en de kans op 'over het hoofd geziene' kinderziektes het grootst is. Een eventuele - (mede) door de potentiële aansprakelijkheidsknelpunten rond zelfrijdende auto's ingegeven - overstap naar een op directe verzekering gebaseerd compensatiesysteem hoeft in dit verband geen achteruitgang te betekenen. Enerzijds omdat via regresvorderingen van verzekeraars het aansprakelijkheidsrecht zijn preventieve prikkelwerking kan blijven vervullen, anderzijds omdat een first-partyverzekeraar in verhouding tot een aansprakelijkheidsverzekeraar effectiever veiligheidsverhogende maatregelen kan stimuleren.

Voor zowel publieke als private 'normstellers' geldt evenwel dat zij slechts zinvol kunnen sturen op veiligheid als er voldoende empirische gegevens beschikbaar zijn over de daadwerkelijke veiligheidseffecten van de diverse typen systemen,

63 Van Wees 2016, p. 33.

64 Vormen van 'pay as you drive'-verzekeringen worden in Nederland o.a. aangeboden onder de naam 'Veilig Rijden'-verzekering (zie www.anwb.nl/verzekeringen/autoverzekering/veilig-rijden/ rapport). 
alsmede over de effectiviteit van risicomitigerende maatregelen in de sfeer van ontwerp en presentatie. Hoewel onderzoek in de vorm van simulatorstudies en testen met geïnstrumenteerde auto's belangrijke indicaties kan opleveren, is onderzoek naar het functioneren van rijtaakautomatiserende systemen in de praktijk essentieel voor het verwerven van de benodigde wetenschappelijke inzichten. Op dit vlak is nog grote winst te behalen. ${ }^{65}$ De verplichting nieuwe voertuigen met ingang van 2022 (mede) voor onderzoeksdoeleinden uit te rusten met een gegevensrecorder voor incidenten (Event Data Recorder) ${ }^{66}$ zal daartoe een zeer belangrijke bijdrage kunnen leveren.

65 Onderzoeksraad voor Veiligheid 2019, p 79 e.v. Zo wordt vastgesteld dat bij de huidige generatie systemen data lang niet altijd worden vastgelegd en opgeslagen. Achteraf is dan niet goed vast te stellen of een systeem was ingeschakeld en hoe dit functioneerde. En als bepaalde gegevens wel worden vastgelegd, gebeurt dat doorgaans in een bedrijfseigen format of worden de data versleuteld opgeslagen, zodat uitlezen niet mogelijk is zonder hulp van de fabrikant.

66 Art. 6 Verordening (EU) 2019/2144. De gegevens die kort vóór, tijdens en onmiddellijk na een botsing door de recorders kunnen worden geregistreerd en opgeslagen, betreffen o.a. de snelheid van het voertuig, het remmen, de positie en de overhelling van het voertuig op de weg, de toestand en de mate van activering van alle veiligheidssystemen van het voertuig, het op 112 gebaseerde eCall-boordsysteem, de remactivering en de relevante inputparameters van de systemen voor actieve veiligheid en ongevalpreventie aan boord van het voertuig. 